\title{
Regulation of Yeast Acid Phosphatase by Orthophosphate and Phenylmercuric Acetate
}

\author{
By P. MILDNER, BLANKA RIES, Ž. GOLUBIĆ* and E. POTO \\ Laboratory of Biochemistry, Department of Biotechnology, \\ Technological Faculty, University of Zagreb, Zagreb, Yugoslavia
}

\section{(Accepted for publication I9 April I972)}

Phosphate regulation of baker's yeast acid phosphatase (EC. 3. I.3.2) has been reported by several authors (Suomalainen, Linko \& Oura, I960; Heredia, Yen \& Sols, I963; McLellan \& Lampen, I963; Schmidt et al. 1963; Günther \& Kattner, I968; Schurr \& Yagil, 197I). In this work the formation of acid phosphatase in baker's yeast during growth in culture media differing in either $\mathrm{KH}_{2} \mathrm{PO}_{4}, \beta$-glycerophosphate or phenylmercuric acetate (PMA) content was studied.

\section{METHODS}

Commercial baker's yeast ('Pliva', Zagreb) or Saccharomyces cerevisiae strain 218 (Technological Faculty Collection, Zagreb) was used. A modification of the medium described by Bandyopadhyay \& Humphrey (1967) was used for cultures. It was a 'low-phosphate' medium containing I5 mg of phosphorus/l and was free of orthophosphate. This 'low-phosphate' medium was supplemented with $0.5 \mathrm{~mm}$ and $\mathrm{I} \mathrm{mM}-\mathrm{KH}_{2} \mathrm{PO}_{4}$ or with $0.5 \mathrm{~mm}$ and I mM- $\beta$-glycerophosphate. When the organisms were grown in the presence of PMA the medium was orthophosphate-free or contained either I mM or Io $\mathrm{mM}^{-} \mathrm{KH}_{2} \mathrm{PO}_{4}$. The organisms were grown aerobically with agitation in $100 \mathrm{ml}$ batches at $28^{\circ} \mathrm{C}$ for $\mathrm{I} 2$ to $\mathrm{I} 8 \mathrm{~h}$.

Cell-free extracts were obtained from suspensions in succinate buffer at $\mathrm{pH} 3.5$ using a Braun mechanical cell homogenizer (model MSK, type 853030). The supernatant obtained after centrifuging at $96000 \mathrm{~g}$ was used as the cell-free extract. Acid phosphatase activity was assayed according to Torriani (1960). Phosphorus was determined by the method of Chen, Toribara \& Warner (1956).

\section{RESULTS}

It was found that formation of acid phosphatase in yeast cells was dependent on the initial concentration of $\mathrm{KH}_{2} \mathrm{PO}_{4}$ or $\beta$-glycerophosphate in the culture medium (Fig. I). Yeast grown in a 'low-phosphate' medium exhibits a relatively high activity of acid phosphatase. When, after Io $h$ of cultivation, $\mathrm{KH}_{2} \mathrm{PO}_{4}(0.5 \mathrm{~mm}$ or I $\mathrm{mm}$ ) was added, repression of acid phosphatase took place (see insert to Fig. I).

It has been recently reported (Schurr \& Yagil, 197I) that $\mathrm{KH}_{2} \mathrm{PO}_{4}$ inhibits competitively yeast acid phosphatase. Kinetic studies performed in our laboratory revealed that $\mathrm{KH}_{2} \mathrm{PO}_{4}$ is a competitive inhibitor of acid phosphatase in the living cells of commercial baker's yeast and in a cell-free extract, with a $K_{i}$ value of $2.4 \times \mathrm{IO}^{-3} \mathrm{M}$. In our experiments total inhibition was achieved with $0 \cdot 1 \mathrm{M}-\mathrm{KH}_{2} \mathrm{PO}_{4}$. The activity of acid phosphatase in phosphate-treated cells was completely restored after washing the cells with water.

* Present address: Research Department 'Pliva', Pharmaceutical and Chemical Works, L. Ribara 89, Zagreb, Yugoslavia. 


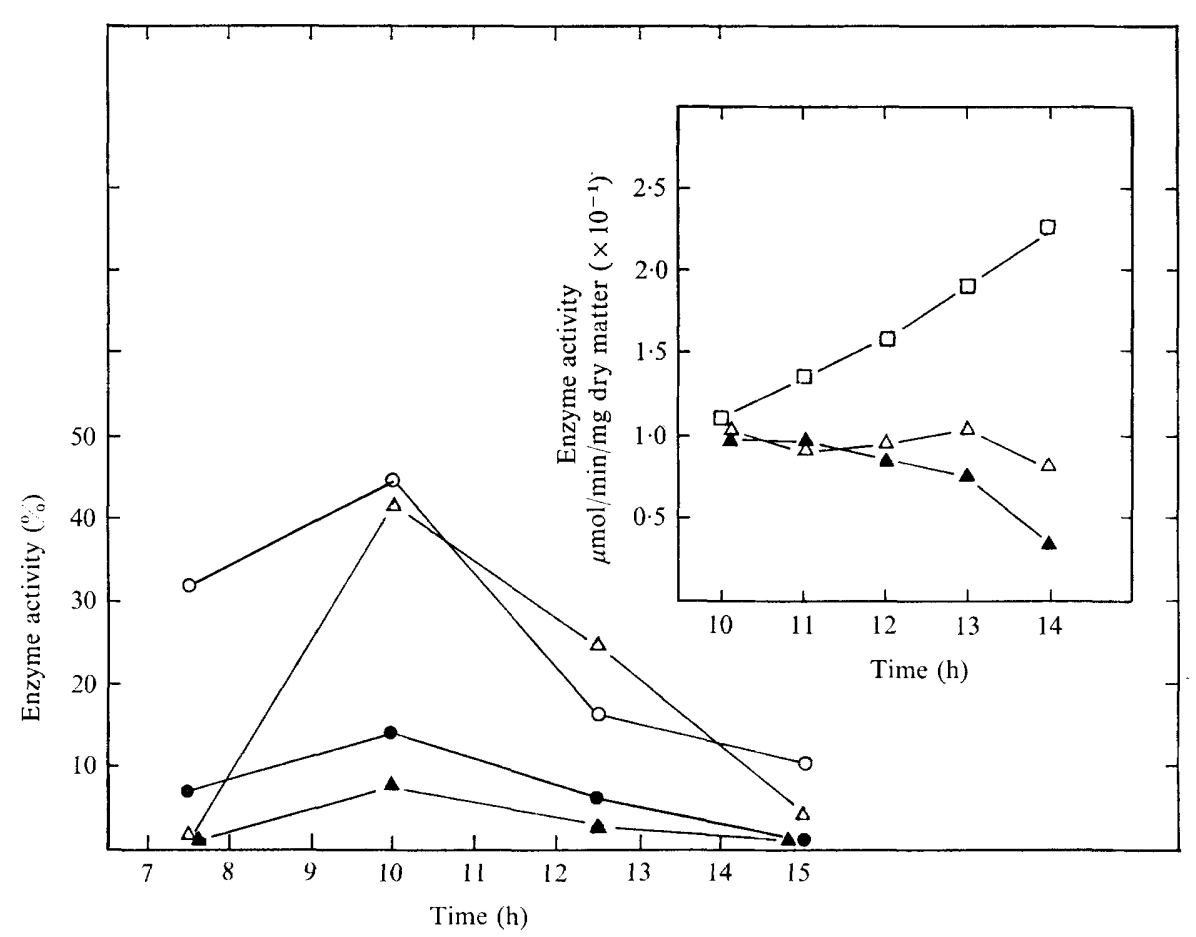

Fig. I. Repression of acid phosphatase by phosphate. Acid phosphatase activity in yeast cells during cultivation at two different concentrations of $\mathrm{KH}_{2} \mathrm{PO}_{4}(\triangle, 0.5 \mathrm{~mm} ; \boldsymbol{\Delta}, \mathrm{I} \mathrm{mm})$ or $\beta$-glycerophosphate $(O, 0.5 \mathrm{~mm}$; $\bigcirc$, I mM). The activity of acid phosphatase of cells grown in the "lowphosphate' medium was taken as $100 \%$. The insert shows the activity of acid phosphatase during growth in the 'low-phosphate' medium ( $\square$ ), and its repression after the addition of $\mathrm{KH}_{2} \mathrm{PO}_{4}$ $(\triangle, 0.5 \mathrm{~mm} ; \Delta, \mathrm{I} \mathrm{mM})$.

Interaction of PMA with yeast acid phosphatase has been reported (Ries \& Suomalainen, 1970). It was shown that $10^{-3} \mathrm{M}$-PMA inhibits the yeast acid phosphatase when added to the assay mixture. In our experiments PMA was added to the growth medium as well at concentrations of $1 \mathrm{IO}^{-5}, \mathrm{IO}^{-6}, \mathrm{IO}^{-7}, \mathrm{IO}^{-8}$ and $\mathrm{IO}^{-9} \mathrm{M}$. It was found that growth was inhibited if the medium contained more than $10^{-7} \mathrm{M}-\mathrm{PMA}$.

In a series of experiments the yeast was cultivated in $10^{-7} \mathrm{M}-\mathrm{PMA}$ for $\mathrm{I} 8 \mathrm{~h}$ in 'low-phosphate' medium and media containing either I $\mathrm{mM}$ or $10 \mathrm{mM}-\mathrm{KH}_{2} \mathrm{PO}_{4}$ and the acid phosphatase activities of the cells determined. PMA $\left(\mathrm{IO}^{-7} \mathrm{M}\right)$ induced acid phosphatase; the highest induction was obtained in the medium containing I mM-phosphate.

Yeast grown in $10^{-7} \mathrm{M}-\mathrm{PMA}$ responded differently to $1 \mathrm{O}^{-3} \mathrm{M}$-PMA added to the assay mixture dependent upon the phosphate concentration of the medium. In 'low-phosphate' medium, only $28 \%$ enzyme activity was retained in the presence of $\mathrm{IO}^{-3} \mathrm{M}-\mathrm{PMA}$, whereas in the medium containing I mM-phosphate, acid phosphatase retained $70 \%$ of its activity. There was no inhibition of acid phosphatase by $\mathrm{IO}^{-3} \mathrm{M}$-PMA if the medium contained Io $\mathrm{mM}-\mathrm{KH}_{2} \mathrm{PO}_{4}$, although at this concentration of orthophosphate the enzyme activity was low. 


\section{DISCUSSION}

The level of acid phosphatase in baker's yeast is influenced by the concentration of the phosphate in the culture medium. When $\beta$-glycerophosphate was the only source of phosphate, acid phosphatase was not repressed initially to the same extent as when $\mathrm{KH}_{2} \mathrm{PO}_{4}$ was used. This observation could be explained by assuming a gradual liberation of the phosphate from the organic ester into the medium. Subsequent addition of $\mathrm{KH}_{2} \mathrm{PO}_{4}$ to 'low-phosphate' medium quickly represses the enzyme.

Phosphate inhibited competitively acid phosphatase in the assay mixture. The fact that phosphate could be removed by washing indicates a high dissociation constant for the phosphate-enzyme interaction.

Acid phosphatase of yeast grown in 'low-phosphate' medium, was inhibited by $10^{-3} \mathrm{M}$ PMA in the assay mixture. Increasing the concentration of phosphate decreased the inhibition. Apparently the yeast grown in phosphate-sufficient medium can counteract the action of PMA more efficiently.

\section{REFERENCES}

Bandyopadhyay, B. \& HUMpHREY, A. E. (1967). Dynamic measurement of the volumetric oxygen transfer coefficient in fermentation systems. Biotechnology and Bioengineering 9, 533-544.

Chen, P. S., Jun., Toribara, T. Y. \& Warner, H. (I956). Microdetermination of phosphorus. Analytical Chemistry 28, 1756-1758.

GÜNTHER, T. \& KATTNER, W. (1968). Über die Funktion der sauren Hefephosphatase. Zeitschrift für Naturforschung $23 \mathrm{~B}, 77-78$.

HEREDIA, C. F., YEN, F. \& Sols, A. (1963). Role and formation of the acid phosphatase in yeast. Biochemical and Biophysical Research Communications 1o, 14-18.

McLellan, W. L., Jun \& LAMPEN, J. O. (I963). The acid phosphatase of yeast. Localization and secretion by protoplasts. Biochimica et biophysica acta 67, 324-326.

Ries, B. \& Suomalainen, H. (1970). Interaction of phenylmercuric acetate with some enzymes and intact cells of baker's yeast. Suomen Kemistilehti 43, 392-395.

Schmidt, G., Bartsch, G., Laumont, M. C., Herman, T. \& Liss, M. (1963). Acid phosphatase of baker's yeast: An enzyme of the external cell surface. Biochemistry 2, I26-I3I.

SCHURR, A. \& YAGIL, E. (197I). Regulation and characterization of acid and alkaline phosphatase in yeast. Journal of General Microbiology 65, 29I-303.

Suomalainen, H., Linko, M. \& OuRA, E. (I960). Changes in the phosphatase activity of baker's yeast during the growth phase and location of the phosphatases in the yeast cell. Biochimica et biophysica acta 37, $482-490$.

ToRriani, A. (1960). Influence of inorganic phosphate in the formation of phosphatases by Escherichia coli. Biochimica et biophysica acta 38, 460-469. 